\title{
GRAMSCI, ESCOLA UNITÁRIA E A FORMAÇÃO HUMANA
}

\author{
GRAMSCI, UNITARY SCHOOL AND HUMAN DEVELOPMENT \\ GRAMSCI, ESCUELA UNITÁRIA Y FORMACIÓN HUMANA
}

\begin{abstract}
Eliesér Toretta Zen
Professor de filosofia do Instituto Federal do Espírito Santo-Ifes. Mestre e doutorando em Educação pelo Programa de Pós-Graduação em Educação da Universidade Federal do Espírito Santo (UFES).

elieserzen@hotmail.com
\end{abstract}

Douglas Christian Ferrari de Melo Doutorando em Educação pelo Programa de Pós-Graduação em Educação da Universidade Federal do Espírito Santo (UFES). Professor da rede pública de ensino de Vila Velha (ES).. dochris@ig.com.br

RESUMO: O artigo tem como escopo refletir, do ponto de vista teórico, sobre a formação humana a partir da vida e obra do pensador italiano, Antonio Gramsci (1891-1937). Nesse sentido, objetiva abordar algumas categorias filosóficas de sua práxis político-pedagógica, entre elas, escola unitária, hegemonia e onilateralidade, como expressões de uma concepção teórica e política de um projeto socialista de sociedade e de ser humano. Nessa perspectiva, a escola unitária, ao integrar de forma dialética trabalho manual e intelectual, a dimensão técnica e política, autonomia intelectual e moral, conforma-se em princípio educativo do processo de formação humana. E, por fim, inaugura um autêntico humanismo em que o ser humano é compreendido como o conjunto das relações sociais, um ser concreto e histórico, um devir humano-social.

PALAVRAS-CHAVE: Gramsci. Escola unitária. Formação humana.

ABSTRACT: The scope of this article is to reflect from the theoretical point of view about the human formation on the basis of Antonio Gramsci's life and work (1891-1937). In this way, this text aims to address some philosophical categories of this Italian thinker's political and pedagogical praxis, such as Unitarian school, hegemony and omnilaterality. These expressions are instruments to build a political and theoretical conception of a socialist project of society and human being. On this perspective, the unitarian school, by integrating in a dialectic way the manual and intelectual job, the technical and political dimensions, the moral and intelectual autonomy, conforms it, in an educational principle of human's formation process. And finally, he inaugurates a authentic humanism in which human being is understood as a group of social relations, a be concrete and historical, a becoming social and human.

KEYWORDS: Gramsci. Unitarian school. Human Formation.

RESUMEN: El artículo tiene como alcance reflejar desde el punto de vista teórico de la formación humana de la vida y el trabajo del pensador italiano Antonio Gramsci (1891-1937). En este sentido, tiene como objetivo hacer frente a algunas categorías filosóficas de su praxis político-pedagógica, entre ellos, la escuela unitaria, hegemonía y onilateralidade, como expresión de una concepción teórica y política de un proyecto socialista de la sociedad y del ser humano. Desde esta perspectiva, la escuela unitaria, mediante la integración del trabajo manual e intelectual dialécticamente, la dimensión técnica y política, autonomía intelectual y moral, se ajusta en principio educativo del proceso de desarrollo humano. Por último, inaugura un auténtico humanismo en el que el ser humano se entiende como un conjunto de relaciones sociales, un ser concreto y de la historia, convirtiéndose en un ser humano-social.

PALABRAS CLAVE: Gramsci. Escuela de unidad. Formación humana.

$\overline{\text { Artigo recebido em janeiro de } 2016}$

Aprovado em março de 2016 


\section{1| INTRODUÇÃO}

Nesse artigo, temos por objetivo, refletir, do ponto de vista teórico, sobre a formação humana a partir dos conceitos do pensador italiano, Antonio Gramsci e as importantes contribuições de Marx, Engels e Lênin. Gramsci, mesmo não sendo pedagogo, desenvolveu uma importante teoria educacional de dimensão política com base na ideia de escola unitária contra a crise pela qual passava a escola italiana após a quebra do modelo de educação jesuítica. Além disso, defendeu que esse novo tipo de escola deveria servir à formação de um novo tipo de intelectual que seria ao mesmo tempo técnico e político, especialista e dirigente. Também afirmou o trabalho como princípio educativo, tema este que pertence à essência do socialismo.

Além da introdução e das considerações finais, este artigo está divido em outras três partes. Na primeira, faremos uma breve biografia do pensamento, relacionando sua vida, o contexto da época e sua atividade política, com o objetivo de compreender contextualmente os seus conceitos. Na segunda parte, nos deteremos sobre sua concepção de escola unitária, subdividido em três partes: as contribuições de Marx, Engels e Lênin; o trabalho como princípio educativo e a união dialética entre trabalho e ensino como princípio educativo na escola unitária. Por fim, a terceira parte será dedicada às implicações para a formação humana.

\section{2 | GRAMSCI: a biografia do seu pensamento}

Gramsci conduziu sua vida política com brilhantismo. Seus textos jornalísticos, publicados no L'Ordine Nuovo e no Avanti, foram escritos com esmero e perspicácia. Na prisão, continuou sua prática intelectual, escrevendo aquela que seria sua obra mais famosa - os escritos fragmentados reunidos posteriormente em uma coleção chamada Cadernos do Cárcere. Tratase de um intelectual que teve em seus escritos a marca muito presente do contexto em que viveu, combinando as atividades política e intelectual. Por isso, antes de expor alguns conceitos, faz-se necessário escrever um pouco sobre quem foi Gramsci e em que contexto escreveu, pois nos ajudará a entender os significados dos conceitos por ele introduzidos ou aprofundados na teoria política contemporânea (ANDERSON, 1989). Gramsci nasceu em 1891, na ilha da Sardenha, região pobre da Itália. Desde muito cedo, aprendeu a viver nas condições difíceis em que viviam as camadas mais baixas da população italiana. Com apenas oito anos de idade passou a morar com a mãe e sete irmãos, após afastar-se do pai, que havia sido preso. Nessa ocasião, uma grave doença o afligiu, deixando-o corcunda. Entre treze e catorze anos, foi obrigado, pelas difíceis condições materiais em que vivia sua família, a deixar os estudos e a trabalhar em uma repartição pública.

Nesse período a Itália vivia uma situação política extremamente conturbada. Sua unificação só se completou sob o comando do Reino Piemontês, dez anos antes do nascimento de Gramsci. Com o apoio da França, Emanuel II, rei de Piemonte, e Camilo Cavour, seu primeiro ministro, em 1859 declararam guerra à Áustria e conseguiram a anexação da parte norte do território italiano e de parte do Estado Pontifício. Pelo lado sul, a unificação foi levada a cabo por Giuseppe Garibaldi que, em 1860, partiu de Piemonte para conquistar o Reino das Duas Sicílias. Para a unificação tornar-se completa, faltava ainda a conquista de Roma, região central do Estado Pontifício, o que só ocorreria dez anos mais tarde (1870), por obra de Garibaldi. A recusa do Papa em aceitar a autoridade de Emanuel II provocou graves conflitos entre a Igreja Católica e a recém-criada "nação" italiana. 
A unificação resultou de uma articulação de grupos sociais desiguais e de equilíbrio instável sob a liderança da burguesia liberal moderna do norte em aliança com os grandes proprietários do sul (COUTINHO, 2003). A unificação era um desejo da burguesia nortista, que necessitava estreitar as relações de troca entre os múltiplos Estados regionais. Esse processo "[...] subjugou o campo à cidade industrial e subjugou a Itália central e meridional à Itália do norte" (GRAMSCI apud DIAS, 2000, p. 57). Para assim proceder, o Estado não abriu mão da centralização de atos de violência, uma ditadura do norte sobre o sul. Os camponeses da ilha de Sardenha, em sua maioria, foram os que mais sofreram.

Foi nesse contexto que Gramsci conseguiu concluir seus estudos secundaristas. Por meio do jornal Avanti!,1 que seu irmão lhe enviava de Turim, veio a ter os primeiros contatos com as ideias socialistas. Na cidade de Cagliari, ainda na Sardenha, passou a frequentar as reuniões do movimento socialista local. Seus primeiros escritos, que datam de 1910, foram publicados em um jornal local que abordava o tema da união sarda. Nesse mesmo ano, conseguiu uma bolsa para estudar em Turim, onde se matriculou na Faculdade de Letras. Naquela época, Turim era uma grande cidade industrial, de concentração operária acentuada, em sua maioria de origem camponesa. Ali as agitações e greves se sucediam.

Em todos os seus escritos após a juventude, época em que participou efetivamente do Partido Socialista, esteve presente a luta contra o determinismo vulgar, que havia tomado parte da ideologia do Partido. O determinismo combinava um culto ao cientificismo com uma interpretação estritamente evolucionista e economicista do marxismo. Por essa ideologia referendava-se a prática política do imobilismo, do fatalismo e do "etapismo" dentro do Partido Socialista Italiano (PSI).

Mas o que já começava a ganhar a atenção dentro do pensamento de Gramsci era o elemento libertador, que se traduzia na importância do papel da vontade, da ação e da cultura na transformação do real (COUTINHO, 2003, p. 11). Já na juventude Gramsci estava convencido de que: "toda a revolução foi precedida por um imenso trabalho de crítica, de penetração cultural, de permeação de ideias em grupos de homens antes refratários e que só pensavam em resolver dia-adia, hora a hora, para si mesmos, seus próprios problemas econômicos e políticos" (GRAMSCI apud COUTINHO, 2003, p. 18).

Foi quando propôs a fundação, em 1917, de uma associação cultural socialista dentro do PSI, que recebeu o nome de "Clube da Vida e da Moral". Esse Clube tinha por objetivo a educação moral e cultural dos jovens socialistas. A importância dada à cultura não finalizou com a fundação dessa associação cultural. Em abril de 1919, juntamente com outros socialistas, lançou o Semanário Cultural Socialista, mais conhecido como jornal L'Ordine Nuovo.

As teses de Gramsci tiveram grande aceitação entre o operariado de Turim, chegando, ao mesmo tempo, em 1920, ao clímax e ao fracasso. Em abril desse ano, os operários de Turim entraram em greve, movimento que ficou conhecido como a greve dos "ponteiros", comandada pelo grupo do L'Ordine Nuovo. Essa greve passou de uma vitória inicial para um desastre final, pelo seu isolamento político, causado, principalmente, pelas acusações e pela falta de apoio do PSI e dos sindicatos.

A Primeira Guerra Mundial desenrolava-se no continente europeu, promovendo uma série de desdobramentos políticos. Gramsci já percebia, em 1917, que a Guerra trazia um novo hábito: "[...] o de não temer um fato novo; primeiro, porque pior do que está não pode ficar, depois, porque se está convencido de que virá o melhor" (GRAMSCI apud DIAS, 2000, p. 87). Além disso, a Guerra também modificou a relação das forças sociais. Mudaram-se as articulações de classes e a formas de ações políticas. Acompanhando a expansão da burguesia, o Estado ampliou seu alcance

${ }^{1}$ Jornal do órgão central do Partido Socialista Italiano. 
à sombra da Liga das Nações, criada após a Guerra, como "organização burguesa mais útil" (GRAMSCI apud DIAS, 2000, p. 110), versão contrária da Internacional Comunista.

No cenário italiano, em 1919, o PSI estava dominado pelos reformistas, por uma confusão ideológica e pela ausência de uma direção, fracionada internamente. O PSI deixou de ser uma vanguarda revolucionária para se tornar mais um partido parlamentar, mantendo-se no limite da democracia representativa. Foi a partir dessa situação e da falta de apoio na greve dos "ponteiros" que Gramsci inicia a ruptura com o Partido, o que resultou na fundação do Partido Comunista Italiano (PCI).

Ideologicamente Gramsci já se encontrava fora do PSI, só faltava um fato material para que isso acontecesse realmente, o que veio acontecer durante o XVII Congresso do PSI, em Livorno, no início de 1921. Nesse congresso, os comunistas - ala mais esquerdista dentro do Partido Socialista - tentaram defender a tese da expulsão dos reformistas e a mudança do nome para Partido Comunista. Derrotados internamente e com a recusa dos centristas de atenderem às suas reivindicações, os comunistas retiraram-se e fundaram o "Partido Comunista da Itália, seção italiana da Internacional Comunista".

Em 1922, Gramsci foi enviado a Moscou como representante do Partido na Internacional Comunista (IC). Nessa oportunidade teve a possibilidade de se aprofundar nas ideias de Lênin. A partir das cartas enviadas de Moscou, aderiu à tese da "frente única". Gramsci entendia que o Partido deveria fazer uma ligação orgânica com os movimentos populares para sair do imobilismo e do isolamento e "fazer política" de modo prático. Nesse período a sociedade italiana passava por um período de grande instabilidade política, marcada pela insustentável situação econômica consequente do pós-guerra. A pequena burguesia esperava por uma reação, uma restauração da ordem. Os ataques aos jornais e às associações operárias e os atentados aos deputados socialistas, sob a égide dos fascistas, seriam para a pequena burguesia a melhor forma de cumprir essa missão. Ante o Estado paralisado, o "Estado informal", o fascismo, ampliava sua ação (DIAS, 2000).

Todos dentro do $\mathrm{PCl}$, nessa época, subestimavam o perigo fascista e uma consequente ditadura, com exceção de Gramsci. Já em 1921, Gramsci lançou um artigo sob o título de II popolo delle scimmie. Em outros artigos Gramsci destacou, ainda, a estratégia fascista de atuar a partir de baixo, à margem do Estado, ou seja, na ilegalidade. O que é possível depreender desse momento é o reconhecimento do Estado como ator político. Com a "Marcha sobre Roma" começou o período de ilegalidade do PCl e, já em 1923, vários membros do Partido foram presos. Nesse mesmo ano foi emitida uma ordem de prisão contra Gramsci, que se encontrava em Moscou, impossibilitando-o de entrar no território italiano. Porém, designado como representante da IC para Viena, Gramsci não ficaria fora da política italiana. Em 1924, Gramsci foi eleito deputado, com a ideia de ser protegido pela imunidade parlamentar. Regressou, então, à Itália, onde participaria, na clandestinidade, das conferências e encontros do $\mathrm{PCl}$, da vida política e parlamentar italiana.

O ano de 1926 não acabaria muito bem: apesar da afirmação de sua liderança, consagrada durante o III Congresso do PCI realizado na cidade francesa de Lyon, Gramsci terminou preso como parte das medidas excepcionais adotadas por Mussolini sob o pretexto de um atentado terrorista do qual o "duce" fora vítima dias antes. Com base na Lei de Segurança Pública, Gramsci foi condenado, em 1928, a cinco anos de confinamento, que se estendeu até 1934, quando foi transferido, sob liberdade condicional, para uma clínica a fim de se tratar de uma doença grave. Não resistiu por muito tempo e morreu em 1937, em consequência de um derrame cerebral.

Apesar de preso e sob censura, mesmo com toda a dificuldade física, Gramsci continuou a produzir e deixou-nos uma vasta obra; esses escritos foram reunidos sob o título Cadernos do Cárcere e publicados em várias edições e em diferentes idiomas. Os Cadernos são prova da inutilidade dos objetivos de sua prisão, em 1926, e consequente condenação, assim proferida pelo promotor fascista: É preciso impedir que esse cérebro funcione durante vinte anos. Sua obra teve 
como grande objetivo a instrumentalização teórico-prático das classes subalternas para "[...] lutar contra as relações de poder vigente, visando superar a situação de dirigência e dominação (situação hegemônica) a que estavam submetidas" (MARTINS, 2008, p. 308). Queria responder a seguinte questão posta após as derrotas socialistas na Europa

Como a classe trabalhadora podia construir uma nova hegemonia em um mundo onde não se podia minimizar a magnitude do poder, as metamorfoses do capitalismo, a complexidade das suas ramificações na cultura, na educação, na religião, nos meios de comunicação, nas novas formas de ideologias totalitárias? (SEMERARO, 2000, p. 10)

Sob a luz dessa questão estará o coração de seu pensamento e, para tanto, construirá novos valores e conhecimentos que deveriam ser difundidos e apropriados, despertando a vontade de constituição de uma nova civilização, uma nova realidade econômica, ética, política e cultural (MARTINS, 2008).

\section{3 | A ESCOLA UNITÁRIA EM GRAMSCI}

\subsection{As contribuições de Marx, Engels e Lênin.}

Embora tenham enfrentado situações distintas, percebe-se que Marx, Engels, Lênin² e Gramsci tiveram muito em comum, sobretudo porque souberam ser homens de seu tempo. Foram sujeitos de um lado, procuravam compreender as relações sociais com os instrumentais teóricos do materialismo histórico e dialético e, de vida, tendo em vista a construção de uma ordem societária superior ao capitalismo, ou melhor, uma ordem cujo desenvolvimento econômico, social, político e cultural beneficia as classes então subalternas.

Marx e Engels não escreveram muito sobre educação. Contudo, suas escassas referências especificamente sobre a questão educacional representam um profundo questionamento para a construção e consolidação de uma teoria escolar socialista. Em 1848, Marx e Engels, em o "Manifesto", além de defenderem a abolição do trabalho das crianças, bem como a adequação entre educação e trabalho, reivindicavam a educação pública e gratuita para todos. Além disso, encontramos as principais premissas para a defesa de um sistema educativo que, realmente, beneficie todos os homens, podendo-se assinalar as seguintes etapas para se chegar a uma educação socialista: 1) a grande indústria, liberada dos encargos da propriedade privada, alcançará seu pleno desenvolvimento, produzindo, em abundância, o suficiente para as necessidades de todos; 2) isto tornará "supérflua" e "impossível" a divisão da sociedade em classes. Na nova sociedade, homens novos desenvolverão suas aptidões em todos os sentidos, desaparecendo a divisão do trabalho.

A educação era, para os dois, uma arma muito importante para acabar com a divisão entre trabalhadores e intelectuais, pois, por ela, o trabalhador teria acesso ao saber, adquirindo condições de "controlar o processo de produção/reprodução dos conhecimentos científicos e técnicos" o "saber" unindo-se ao "fazer" fará com que o operário ultrapasse os limites do senso comum e destrua a barreira que existe entre ele e o intelectual. A busca desta unidade é a única condição

\footnotetext{
2 Para construção desse tópico, lançamos mão de algumas obras dos autores supracitados. De Karl Marx foram: "Os manuscritos econômico-filosóficos", "O capital: crítica da economia política", "Crítica do programa de Gotha" e "Sobre a questão judaica". De Karl Marx e Friedrich Engels foram: "Manifesto comunista”, "Textos sobre educação e ensino". De Vladimir Lênin foram: "Três fontes e as três partes constitutivas do Marxismo", "O estado e a revolução" e "Cadernos sobre a dialética de Hegel".
} 
para se passar da unilateralidade para a onilateralidade do homem, para se chegar ao homem completo ou integral.

Em Marx, o conceito de unilateralidade está fundamentado na divisão do trabalho manual e intelectual, que produziu, na sociedade, a divisão de classes. Esta divisão gerou a "unilateralidade", uma vez que proporcionou ao homem uma dedicação diversificada no exercício de suas atividades. O trabalho alienado produz a "unilateralidade" o trabalhador se converte em um objeto estranho e desumano. O perigo da "unilateralidade" é o desenvolvimento parcial do homem. E para a sociedade isto significa um trabalho sem muitas exigências culturais. Em contraponto a unilateralidade, a "onilateralidade" significa desenvolvimento total, completo, multilateral, em todos os sentidos, das faculdades e das forças produtivas, do ser humano. "Onilateralidade" significa, portanto, desenvolvimento global do homem realizado sob as bases do trabalho como atividade vital e princípio da escola socialista.

Lênin é responsável pela transformação das teses pedagógicas de Marx em fundamento para o sistema escolar do primeiro estado socialista do mundo. Oficializou as teses marxistas, conseguindo que elas exercessem uma decisiva influência também no campo pedagógico, desde a implantação do socialismo na Rússia até os nossos dias. Marx sempre teve uma atitude de particular atenção com tudo o que dizia respeito à educação e à formação da juventude. Nada, porém formal e oficial como em Lênin. Nele sobressaía o impulso surgido naturalmente como quem acreditava que a escola deveria servir à causa da construção de uma nova sociedade, atuando como instrumento de formação da personalidade de um novo homem.

Lênin aliava a uma convicção intelectual própria de um militante consciente, um entusiasmo em realizar a proposta pedagógica de Marx, ou seja, em unir estudo e trabalho produtivo. Acreditava que a luta ideológica não podia estar separada da luta política e que cultura e revolução formavam uma relação orgânica. Gramsci foi aquele que pôde visualizar o desenvolvimento do capitalismo por mais tempo no século $X X$, o que fez com que ele pudesse ter uma dimensão maior dos contornos adquiridos pelas estruturas e superestruturas em seus desdobramentos históricos. Isso deu ao olhar sempre atento de Gramsci mais possibilidades de ver melhor que o âmbito das relações sociais de produção material se alterou em concomitância com as modificações efetivas no plano das relações sociais político-ideológicas, mas mantendo a formação econômica e social sob a dominação e direção burguesa e tornando todas as relações, além de hegemonizadas pela burguesia, caracterizadas por um processo de complexificação que só fez aprofundar-se até os primeiros anos do século XXI.

Em relação à educação, os escritos de Gramsci desenvolveram-se em torno de três temas:

a) o papel da educação como parte do processo da formação da hegemonia cultural nas sociedades capitalistas burguesas;

b) as possibilidades de educação formal e não formal como lugares de formação de consciência revolucionária, contra-hegemônica anterior a qualquer transição revolucionária;

c) os princípios que devem fundamentar a pedagogia socialista de uma sociedade pós-revolucionária.

\subsection{0 trabalho como princípio educativo}

Gramsci faz uma crítica à divisão fundamental da escola em clássica e profissional. Para ele tal divisão era um esquema racional que visava perpetuar os valores e os privilégios da burguesia: a escola profissional destinava-se às classes instrumentais, ao passo que a clássica destinava-se às classes dominantes e aos intelectuais. O desenvolvimento da base industrial, tanto na cidade como no campo, provocava uma crescente necessidade do novo tipo de intelectual urbano: 
"desenvolveu-se, ao lado da escola clássica, a escola técnica (profissional, mas não manual), o que colocou em discussão o próprio princípio da orientação concreta de cultura geral, da orientação humanista da cultura geral fundada sobre a tradição greco-romana" (GRAMSCI, 1998, p. 109). Eis por que, para o pensador sardo, na escola unitária, a última fase deve ser concebida e organizada como a fase decisiva, na qual se tende a criar os valores fundamentais do humanismo, a autodisciplina intelectual e a autonomia moral, necessárias a uma posterior especialização:

A escola criadora não significa uma escola de inventores e descobridores; ela indica uma fase e um método de investigação e de conhecimento, e não um programa predeterminado que obrigue à inovação e à originalidade a todo custo. Indica que a aprendizagem ocorre notadamente graças a um esforço espontâneo e autônomo do discente, e no qual o professor exerce apenas uma função de guia amigável, como ocorre ou deveria ocorrer na universidade. Descobrir por si mesmo uma verdade, sem sugestões e ajudas exteriores, é criação (mesmo que a verdade seja velha) e demonstra a posse do método; indica que, de qualquer modo, entrou-se na fase da maturidade intelectual na qual se podem descobrir verdades novas. (GRAMSCI, 1998, p.115).

Dessa forma, a lógica formal (método de pensar) não se aprende no ar e a escola deve se organizar e funcionar de modo que possibilite aos filhos das classes trabalhadoras superarem as enormes dificuldades que têm em se apropriar do conhecimento historicamente acumulado pela sociedade. Assim, na escola unitária se daria a possibilidade da formação omnilateral, do ser humano integralmente desenvolvido, integrando as dimensões do fazer e do saber, do técnico e do político, especialista e dirigente, profissional e cidadão.

Segundo Jesus (2005, p. 57) no período de 1918 a 1926, na Itália, o debate sobre a escola profissional e da cultura geral consagrou uma terminologia específica: "escola do saber desinteressada". Gramsci afirmava que, no modo de produção socialista, a escola não deveria ser imediatamente interessada, oposta àquela aristocrática, considerada, por ele, como interessada, por servir a uma minoria de privilegiados, por destinação da família. Essa escola aparentemente desinteressada trazia de fato, um interesse imediato que era formar a elite dirigente,

\begin{abstract}
A tendência, hoje, é a de abolir qualquer tipo de escola "desinteressada" (não imediatamente interessada) e formativa, ou conservar delas tão somente um reduzido exemplar destinado a uma pequena elite de senhores e de mulheres que não devem pensar em se preparar para um futuro profissional, bem como a de difundir cada vez mais as escolas profissionais especializadas, nas quais o destino do aluno e sua futura atividade são predeterminados. A crise terá uma solução que, racionalmente, deveria seguir esta linha: escola única inicial de cultura geral, humanista, formativa, que equilibre equanimemente o desenvolvimento da capacidade de trabalhar manualmente (tecnicamente, industrialmente) e o desenvolvimento das capacidades de trabalho intelectual. (GRAMSCI, 1998, p. 110).
\end{abstract}

Assim, o adjetivo interessado, atribuído por Gramsci, opõe-se a desinteressado que comporta um horizonte amplo, de longo alcance, isto é, que interessa objetivamente não apenas a indivíduos ou a pequenos grupos, mas à coletividade e até à humanidade inteira. Desse modo, a expressão "desinteressada" não quer dizer neutro ou indiferente. Pelo contrário, na concepção gramsciana uma escola "desinteressada" vai significar que ela tem a função de contribuir na formação humana omnilateral dos seres humanos. Sendo assim, exige-se deste tipo de escola que ela desenvolva as possibilidades e os sentidos humanos, sem preocupação com a especialização. Assim para Gramsci (1982, p. 125) "o advento da escola unitária significa o início de novas relações entre o trabalho intelectual e o trabalho industrial, não somente na escola, mas em toda a vida social". Desse modo, para Gramsci (1998, p. 125): 
a escola tradicional era oligárquica, pois era destinada à nova geração dos grupos dirigentes, destinada por sua vez a tornar-se dirigente: mas não era oligárquica pelo seu modo de ensino. Não é a aquisição de capacidades diretivas, não é a tendência a formar homens superiores que dá a marca social de um tipo de escola. A marca social é dada pelo fato de que cada grupo social tem um tipo de escola próprio, destinado a perpetuar nesses grupos uma determinada função tradicional, diretiva ou instrumental. Se se quer destruir essa trama, portanto, deve-se evitar a multiplicação e graduação dos tipos de escola profissional, criando-se, ao contrário, um tipo único de escola preparatória (elementar média) que conduza o jovem até os umbrais da escolha profissional, formando-o entrementes como pessoa capaz de pensar, de estudar, de dirigir ou de controlar quem dirige.

Por certo, o filósofo italiano defende a necessidade de criação de uma escola única, de cultura geral e profissional na qual a formação humana supere a fragmentação entre as dimensões intelectual e manual do trabalho produzida pela sociedade capitalista. Essa escola busca formar humanamente o trabalhador desenvolvendo harmoniosamente as dimensões do trabalho manual e intelectual, do especialista e dirigente, do "Homo Faber" e do "Homo Sapiens". Não é a aquisição de capacidades diretivas que confere a escola uma marca elitista. Se se quer superar a escola oligárquica e elitista, portanto, deve-se, no entender de Gramsci, evitar a separação entre escola profissional e escola humanista, criando-se, ao contrário, um tipo único de escola que prepare os jovens formando-os onilateralmente. Assim argumenta:

A escola unitária ou de formação humanista ou de cultura geral deveria se propor a tarefa de inserir os jovens na atividade social, depois de tê-los levado a certo grau de maturidade e capacidade, à criação intelectual e prática e a certa autonomia na orientação e na iniciativa. Do ensino quase puramente dogmático, no qual a memória desempenha um grande papel, passa-se à fase criadora ou de trabalho autônomo e independente; da escola com disciplina de estudo imposta e controlada autoritariamente passa-se a uma fase de estudo ou de trabalho profissional na qual a autodisciplina intelectual e a autonomia moral são teoricamente ilimitadas. (GRAMSCI, 1998, p. 114).

Desse modo, para o pensador sardo a escola unitária em sua organização curricular possibilitará aos estudantes a construção de uma autodisciplina intelectual e moral nos estudos superando o caráter impositivo e autoritário da disciplina imposta de forma autoritária e mecânica. Portanto, a escola unitária como escola criadora possibilitaria por meio do protagonismo dos estudantes o desenvolvimento da autodisciplina intelectual e da autonomia moral necessária a uma formação humana integrada:

Eis porque, na escola unitária, a última fase deve ser concebida e organizada como a fase decisiva, na qual se tende a criar os valores fundamentais do "humanismo", a autodisciplina intelectual e a autonomia moral necessárias a uma posterior especialização, seja ela de caráter científico (estudos universitários), seja de caráter imediatamente prático-produtivo (indústria, burocracia, organização das trocas, etc.). (GRAMSCI, 1982, p 124).

Sob este aspecto, "se insere no quadro de suas preocupações no sentido de tornar hegemônico um "centro unitário de cultura", apresentando o que ele chama de "esquema de organização do trabalho cultural" (GRAMSCI, 1977, p. 1.539). Integrando um programa político em direção à igualdade social, a "escola unitária" é uma referência para a crítica às desigualdades sociais, produzidas pelo sistema capitalista, e que se exprimem nas diversas instâncias da sociedade e da cultura, como também na escola. O seu significado é muito amplo, parâmetro da análise de Gramsci sobre a organização da cultura. Refere-se à luta pela unificação do ser humano como possibilidade de realização, como devir. 
De acordo com o pensamento educacional de Gramsci (1998, p. 120), o conceito do equilíbrio entre ordem social e ordem natural sobre o fundamento do trabalho, da atividade teórico-prática do homem, cria os primeiros elementos de uma intuição do mundo liberta de toda magia ou bruxaria, e fornece o ponto de partida para o posterior desenvolvimento de uma concepção histórico-dialética do mundo, para a compreensão do movimento e do devenir, para a valorização da soma de esforços e de sacrifícios que o presente custou ao passado e que o futuro custa ao presente, para a concepção da atualidade como síntese do passado, de todas as gerações passadas, que se projeta no futuro.

Para Manacorda (2008) a afirmação do trabalho como princípio educativo é um tema que pertence à essência do socialismo e do pensamento de Gramsci. Assim como Gramsci, Marx e Engels colocaram o trabalho produtivo no centro de suas formulações teóricas, incluindo peda- gógicas, porque para eles o trabalho é a chave de compreensão da realidade. Explica-se o homem pelo trabalho. O homem chega a ser homem em virtude dessa atividade chamada trabalho. Por ela, o homem produz a sociedade e produz a si mesmo. O trabalho constrói e educa, constituindo-se no princípio da vida e da escola. O trabalho tem uma dimensão transformadora da natureza e do homem. Nesse sentido, o homem ao transformar a natureza externa (mundo, sociedade) transforma sua própria natureza, enquanto parte da totalidade viva e do intercambio que estabelece com a própria natureza (água, solo, ar) elementos necessários para manter sua própria vida.

\section{4 | A FORMAÇÃO HUMANA A PARTIR DA PROPOSTA DE ESCOLA UNITÁRIA}

Como vimos anteriormente, para o filósofo italiano o ser humano é compreendido como o conjunto das relações sociais do qual faz parte, é nesse contexto que participa de uma determinada cultura na qual forma suas concepções de conhecimento e de valores relativos à vida social. Quem é o ser humano, para Gramsci? É um ser concreto, situado na e com a história, participando como sujeito das relações sociais nas quais se constitui enquanto humano-social. Em sua concepção materialista e histórica o ser humano se define por aquilo que faz. Ele é o produtor e o produto do seu trabalho, portanto, se autoproduz pelo trabalho, enquanto princípio educativo. Desse modo, a concepção humanista historicista é uma dimensão da concepção filosófica de Gramsci e se constitui central na sua compreensão de ser humano, como se pode verificar:

\footnotetext{
[...] deve-se conceber o homem como uma série de relações ativas (um processo), no qual, se a individualidade tem a máxima importância, não é, todavia o único elemento a ser considerado. A humanidade que se reflete em cada individualidade é composta de diversos elementos: 1) o indivíduo; 2) os outros homens; 3) a natureza. O indivíduo não entra em relação com os outros homens por justaposição, mas organicamente, isto é, na medida em que passa a fazer parte de organismos [...] Desta forma, o homem não entra em contato com a natureza simplesmente pelo fato de por ser ele mesmo natureza, mas ativamente, por meio do trabalho e da técnica. E mais: essas relações não são mecânicas. São ativas e conscientes, ou seja, correspondem a um grau maior ou menor de inteligibilidade que delas tenha o homem individual. Daí ser possível que cada um transforma a si mesmo, se modifica, na medida em que transforma e modifica todo o conjunto das relações do qual ele é o ponto central. (GRAMSCI, 1978 apud MARTINS, 2008, p. 211-212).
}

Assim, para filósofo sardo, sendo o ser humano um ser histórico, inacabado, por fazer-se na história e pela história, não há nada além do horizonte histórico que possa definir uma natureza humana a priori, metafisicamente dada, como acreditam as diferentes formas de religiões e os idealismos. Desse modo, para Gramsci, todos os seres humanos se tornam humanos em contato 
com a sociedade e o ambiente cultural do qual fazem parte. É no contexto das relações sociais que determinadas formas de pensar, sentir e agir são formadas, em que emerge uma determinada concepção de mundo e de sociedade, mesmo que difusa e fragmentada. Portanto, todos os seres humanos são considerados filósofos, pois têm a capacidade de reflexão, de pensar, mesmo que não desempenhe na sociedade a função de filósofo. Essa concepção de mundo desagregada, fragmentada e difusa, são características do senso comum. Para o pensador sardo, o senso comum é:

\begin{abstract}
[...] uma visão de mundo tão estratificada que nela existem elementos de "bom senso", um "núcleo sadio" que se liga ao pensamento mais desenvolvido e que é a razão pela qual se torna praticamente impossível separar a filosofia "científica" da filosofia "vulgar", pois está é apenas um conjunto desagregado de ideias e opiniões. O que as distingue é o fato de que, enquanto a filosofia "científica" é uma concepção unitária, o "senso comum" não pode ser elevado ao nível de uma "ordem intelectual" porque lhe falta a unidade e coerência. (GRAMSCI, 1978, p. 176).
\end{abstract}

Dessa feita, se pode verificar um núcleo sadio do senso comum que o filósofo italiano compreendia como sendo o bom senso. Esse núcleo sadio do senso comum deve se converter por meio de um trabalho educativo em um pensar coerente e unitário. Refletindo sobre a questão da formação humana nos escritos de Gramsci, a passagem do senso comum ao bom senso garantiria que os estudantes alcançassem uma nova concepção de mundo que fosse unitária e coerente. Mas esse processo formativo não se daria de forma espontânea e sem esforços por parte dos estudantes. Na verdade exige-se um processo educativo que possibilite o desenvolvimento da autodisciplina intelectual e moral, necessárias para que os estudantes adquiram desde cedo o pensar de forma coerente a realidade.

Em Concepção Dialética da História Gramsci (1978), argumenta que a mesma deve possibilitar a superação das concepções ingênuas e incoerentes (alienadas) presentes no senso comum para uma concepção coerente e unificada da realidade (crítica). Nessa perspectiva uma das tarefas da filosofia da práxis por meio dos intelectuais orgânicos consiste em contribuir para a elevação intelectual e moral das massas a fim que as mesmas possam alcançar uma concepção coerente e unificada do mundo.

Gramsci (1978) faz uma crítica à concepção que vê no intelectual um ser separado das relações sociais e de que o trabalho intelectual não comporta o trabalho manual. Destarte, não é a natureza da atividade intelectual ou manual que traz em si mesma o caráter dual, mas o lugar que ela ocupa nas relações sociais, que acarretará uma valorização ou não da atividade no seio das relações de produção da vida material e, por conseguinte a dicotomia entre ambas. A escola unitária deveria servir à formação de um novo tipo de intelectual que seria ao mesmo tempo técnico e político, especialista e dirigente, profissional e cidadão. Sendo assim, se estabelece uma luta entre a velha concepção do mundo, fragmentada e acrítica do senso comum e a nova concepção do mundo, unitária e dirigente ${ }^{3}$, própria da filosofia. Contudo, não se quer dizer que para Gramsci o senso comum não seja importante; ele o é na medida em que fornece às massas orientação no mundo,

\footnotetext{
${ }^{2}$ Segundo Soares (2000, p. 435) "a aquisição de capacidades para o exercício de funções dirigentes é justamente o que Gramsci concebe como o aspecto mais positivo da 'escola tradicional'. Esta escola, para ele, não era democrática. Ela formava os filhos das elites que deveriam se tornar dirigentes. Mas o elitismo não estava nos seus métodos de ensino, já que a preparação para 'se orientar e dirigir na vida' não caracteriza uma escola como elitista. O que marca socialmente a escola é a existência de um tipo de escola diferente para cada grupo social. Por isso, Gramsci insiste no combate a profissionalização do ensino, mostrando que a multiplicação de escolas profissionais agravava o problema do dualismo escolar, em que a escola oferecida ao povo só tendia a 'eternizar as diferenças tradicionais'".
} 
agrega determinadas concepções de pensar e agir sedimentados na cultura da qual todo ser humano participa em maior ou menor grau. No entanto, é preciso partir do senso comum para superá-lo até chegarmos ao seu núcleo sadio, o bom senso, e daí até uma concepção unificada e coerente da realidade. Assim o processo educativo, para Gramsci, necessita de uma orientação e deve buscar desenvolver uma disciplina autoconsciente nos estudantes de forma que os mesmos adquiram a autodisciplina nos estudos por meio inclusive de certo esforço muscular nervoso por parte do estudante.

Portanto, Gramsci combatia, ao mesmo tempo, o espontaneísmo e o autoritarismo. O primeiro por descuidar do processo formativo e o segundo por sufocá-lo, com uma forma autoritária e nefasta de disciplina, que não sendo construída de forma consciente pelo educando, se torna prejudicial à sua formação. A argumentação do pensador sardo nos leva a afirmar a necessidade do desenvolvimento da autodisciplina intelectual e moral das classes subalternas, como condição para a formação humana omnilateral. A propósito é nesse horizonte ético-político que se situa o núcleo fundamental de toda a obra de Gramsci. Por certo, o seu pensamento e a sua militância radicam-se no sentido amplo e profundo de sua concepção educacional, como a que integra a formação humanística e a formação profissional, possibilitando a reforma intelectual e moral do educando o que implica um autêntico humanismo-historicista. Nesse sentido, diz Gramsci (1982, p. 08, grifo nosso) que um processo educativo que tenha como objetivo a formação humana integrada deve possibilitar o desenvolvimento da totalidade das dimensões humanas que forme o educando "[...] não apenas orador puro e superior, todavia, ao espírito matemático abstrato da técnica-trabalho, eleva-se à técnica-ciência e à concepção humanista histórica, sem a qual se permanece "especialista" e não se chega a "dirigente" (especialista mais político)".

Nesse contexto é que o filósofo italiano tece crítica contundente à escola quando esta reproduz a separação entre trabalho intelectual e manual engendrada pelas relações sociais capitalistas de produção, que separa o saber do fazer, a concepção da execução, o trabalho complexo do trabalho simples, o profissional do cidadão. Tal separação não é natural e sim ideológica e visa manter a dominação e os interesses particulares da classe que está no poder sobre as demais. Essa dicotomia entre trabalho intelectual e manual sendo ideológica desvia a atenção das funções reais, no interior da vida social e produtiva, para os "aspectos técnicos" do trabalho. Dessa feita, em Americanismo e fordismo (GRAMSCI, 2008), o pensador sardo, afirma que a mesma ao requerer novos métodos de produção demanda mudanças nas formas de organização do trabalho e da própria atividade teórico-prática do trabalhador. Mas discorda da concepção de Taylor, para quem o trabalhador não passaria de um gorila domesticado. Sendo assim, argumenta que:

Taylor, de fato, exprime com cinismo brutal a finalidade da sociedade americana, de desenvolver no trabalhador posturas maquinais mínimas e automáticas, eliminar o antigo senso psicofísico do trabalho profissional qualificado, que demandava uma participação ativa da inteligência, da fantasia, da iniciativa do trabalhador, e reduzir as operações produtivas ao aspecto físico maquinal somente. (GRAMSCI, 2008, p. 66-67).

Como se pode verificar, para Gramsci o desenvolvimento da indústria como atividade teórico-prática possibilitaria o domínio não só da natureza como matéria bruta, mas do próprio trabalhador, dos seus instintos, de sua vontade e de sua consciência. Portanto, não se trata de um adestramento mecânico do trabalhador ao processo produtivo como queria, por exemplo, Ford e Taylor:

Desse ponto de vista, é o caso de estudar as iniciativas puritanas dos industriais americanos como as de Ford. Está claro que estes não se preocupam com a humanidade, com a espiritualidade do trabalhador, que imediatamente é aniquilada. Esta humanidade e espiri tualidade não pode realizar-se senão no mundo da produção do trabalho, na criação produtiva; esta era a máxima do artesão, do demiurgo, quando a personalidade do 
trabalhador se refletia completamente no objeto criado [trabalho não alienado], quando ainda era forte a ligação entre arte e trabalho. (GRAMSCI, 2008, p. 67, grifo nosso).

Por sua vez, em toda atividade humana há um vinculo entre as dimensões física e intelectual, prática e teórica, de forma que não é possível, sob pena de desintegração e aniquilamento do ser do trabalhador, separar a atividade manual da atividade intelectual. Convergindo com essa análise, afirma Gramsci (1982, p. 7):

\begin{abstract}
Na verdade, o operário ou proletário, por exemplo, não se caracteriza especificamente pelo trabalho manual ou instrumental, mas por este trabalho em determinadas condições e em determinadas relações sociais (sem falar no fato de que não existe trabalho puramente físico e de que mesmo a expressão de Taylor, "gorila amestrado", é uma metáfora para indicar, um limite numa certa direção: em qualquer trabalho físico, mesmo no mais mecânico e degradado, existe um mínimo de qualificação técnica, isto é, um mínimo de atividade intelectual criadora).
\end{abstract}

Realmente, em sua concepção educacional, Gramsci redimensiona o valor da escola como campo de conscientização do processo social contraditório, de superação de valores e de mudança da história. Nesse sentido, outro aspecto considerado importante de sua obra é a relação entre sua concepção de educação e a análise que fez sobre a formação e função dos intelectuais num papel orgânico no seio do bloco histórico ${ }^{4}$. Assim, a práxis educativa é entendida como um conjunto de relações hegemônicas que não podem se limitar à situação escolar. Como vimos anteriormente, o pensador sardo faz uma crítica à divisão fundamental da escola em clássica e profissional. Para ele, tal divisão era um esquema racional que visava perpetuar os valores e os privilégios da burguesia.

\title{
5 | CONSIDERAÇÕES FINAIS
}

Como guisa de conclusão, a proposta educacional de Gramsci não deve ser compreendida separada da luta por um novo projeto de sociedade, a sociedade socialista ou comunista o que por sua vez representa a possibilidade de autoconstrução de um novo ser humano. A escola não deveria ser imediatamente interessada, oposta àquela aristocrática, considerada, por ele, como interessada, por servir a uma minoria de privilegiados, por destinação da família. Destarte, somente uma escola dessa natureza poderá unir trabalho intelectual e manual; teoria e prática; formação profissional e formação geral; contribuindo para uma formação humana emancipatória. Em síntese, o filósofo italiano advoga que a escola nessa perspectiva não ficaria limitada a ser um instrumento a serviço da perpetuação da sociedade burguesa, mas pode converter-se em espaço e tempo que possibilite um processo formativo crítico alternativo das relações sociais capitalistas ${ }^{5}$.

\footnotetext{
${ }^{4}$ De acordo com Mayo (2004, p. 40) "as pessoas que trabalham pela transformação social, nesse caso - o proletariado procurando transformar o Estado burguês - tinham de se engajar em uma 'guerra de posição', um processo de organização social e influencia cultural de amplo alcance. É por meio desse processo que o grupo cria, junto com outros grupos e setores da sociedade, um bloco histórico, o termo que Gramsci utiliza para descrever a maneira complexa na qual as classes ou suas frações estão relacionadas".

${ }^{5}$ Para Damasceno (1989, p. 23) "É possível negar que a educação seja um mero instrumento da classe dominante. Essa ótica de análise realça o caráter contraditório e dialético da sociedade e da educação, procurando explicar a contribuição das práticas pedagógicas realizadas com a participação da classe trabalhadora para o movimento em busca da hegemonia desta classe que tem lugar na sociedade civil".
} 


\section{Referências}

ANDERSON, P. Considerações sobre o marxismo ocidental. 2. ed. São Paulo: Brasiliense, 1989.

COUTINHO, C. N. Gramsci: um estudo sobre seu pensamento político. 2. ed. Rio de Janeiro: Civilização Brasileira, 2003.

DAMASCENO, M. N. A relação trabalho/educação e a escola do trabalhador. 1989. Texto mimeografo.

DIAS, E. F. Gramsci em Turim: a construção do conceito de hegemonia. São Paulo: Xamã, 2000.

GRAMSCI, A. Quaderni del Carcere. Edição crítica do Instituto Gramsci. Org. Valentino Gerratana, ed. Einandi, Torino, 1977.

Concepção dialética da história. 3. ed. Rio de Janeiro: Civilização Brasileira, 1978.

Os intelectuais e a organização da cultura. 4.

ed. Tradução Carlos Nelson Coutinho. Rio de Janeiro: Civilização Brasileira, 1982.

Os intelectuais e a organização da cultura. São Paulo: Circulo do livro, 1998.

$\overline{2008 .}$

Americanismo e fordismo. São Paulo: Hedra,

JESUS, A. T. de. O pensamento e a prática escolar de Gramsci. 2. ed. Campinas: Autores Associados, 2005.

LÊNIN, V. As três fontes e as três partes constitutivas do marxismo. São Paulo: Expressão Popular, 2003.

Cadernos sobre a dialética de Hegel. Rio de Janeiro: Editora UFRJ, 2011. (Pensamento Crítico, 16). v. 1.

O estado e a revolução. Santa Catarina: Clube de Autores, 2009.
MANACORDA, M. A. O princípio educativo em Gramsci: americanismo e conformismo. Campinas: Editora Alínea, 2008.

MARTINS, M. F. Marx, Gramsci e o conhecimento: ruptura ou continuidade? Campinas:Autores Associados, 2008.

MARX, K. Crítica do programa de Gotha. São Paulo: Boitempo, 2012.

O capital: crítica da economia política: o processo de produção do capital. São Paulo: Boitempo, 2013. Livro I.

Os manuscritos econômico-filosóficos. Tradução Alex Martins. São Paulo: Martin Claret, 2002. po, 2010. Sobre a questão judaica. São Paulo: BoitemMARX, K.; ENGELS, F. Manifesto comunista. São Paulo: Boitempo, 1999.

Textos sobre educação e ensino. Campinas: Navegando, 2011.

MAYO, P. Gramsci, Freire e a educação de adultos: possibilidades para uma ação transformadora. Tradução Carlos Alberto Silveira Netto Soares. Porto Alegre: Artmed, 2004.

SEMERARO, G. O marxismo de Gramsci. Gramsci e o Brasil. 2000. Disponível em: <http://www.acessa.com/ gramsci/?page=visualizar\&id=289>. Acesso em: 06 set. 2014.

SOARES, R. D. A concepção gramsciana sobre o estado e o debate sobre a escola. Ijuí/RS: Editora Unijuí, 2000. 